\title{
Nociception in the Skin: nociceptors are no longer the only actors*
}

\section{La nociception cutanée par les cellules de Schwann}

\author{
M. Cherpi · A. Delage $\cdot$ T. Paul $\cdot$ M. Renard
}

(C) Lavoisier SAS 2020

\begin{abstract}
Résumé Les nocicepteurs à terminaisons libres ont longtemps été considérés comme les seuls senseurs nociceptifs dans la peau. Abdo et al. réévaluent le rôle des cellules de Schwann (CSs), cellules gliales de soutien du système nerveux périphérique, dans la perception de la douleur chez la souris. Après observation de la morphologie et de la localisation des CSs et des fibres nociceptives dans la peau, les chercheurs s'intéressent à leur relation fonctionnelle. Ils génèrent des souris exprimant des canaux ioniques photosensibles à la surface des CSs. Cela leur permet de les stimuler spécifiquement (par optogénétique) tout en mesurant la réponse électrique du nerf palmaire. En combinant l'excitation ou l'inhibition des CSs avec des tests comportementaux, ils mesurent la capacité des CSs à sensibiliser les souris à la douleur thermique et mécanique. Enfin, des CSs sont isolées pour évaluer leur capacité à répondre à un stimulus mécanique. Les observations par microscopie électronique et à fluorescence révèlent que les nocicepteurs se trouvent entourés
\end{abstract}

M. Cherpi

BSc in Molecular and Cellular Biology,

University of Nantes, France

A. Delage $(\triangle)$

BSc in Physiology, University of Lyon, France

e-mail : adelage@etu.unistra.fr

T. Paul

BSc in Biochemistry, University of Rennes, France

M. Renard

BSc in Molecular and Cellular Biology,

University of Bretagne Sud, France

M. Cherpi $\cdot$ A. Delage $\cdot$ T. Paul $\cdot$ M. Renard École universitaire de recherche interdisciplinaire sur la douleur (EURIDOL Graduate School of Pain), Joint Master in Neuroscience,

université de Strasbourg, faculté des sciences de la vie,

28, rue Goethe, F-67000 Strasbourg, France

* JC report written from Abdo et al., Science (2019) 365:695-99. par le cytoplasme des CSs dans le derme et accolés à ces dernières dans l'épiderme. Ce complexe glioneural se ramifie au niveau subépidermal. Les chercheurs décident ainsi d'appeler ces cellules gliales « cellules de Schwann nociceptives » (CSn). Leur stimulation par optogénétique révèle une augmentation de l'activité électrique des fibres nociceptives, des comportements « de douleur » chez la souris, et augmente la sensibilité des souris aux stimuli douloureux mécaniques et thermiques. L'inhibition via optogénétique des CSn diminue leur sensibilité aux stimuli mécaniques mais ne modifie pas leur sensibilité aux stimuli thermiques. L'enregistrement unicellulaire des CSn révèle qu'elles sont hautement sensibles aux stimuli mécaniques. Les auteurs de cette étude ont découvert un nouveau type de cellule de Schwann nociceptive jouant un rôle important dans la genèse et modulation de la nociception cutanée.

Mots clés Nociception · Douleur · Peau - Schwann · Nocicepteurs · Souris

\section{Introduction}

Nociceptors are specialized high-threshold sensory neurons that allow living organisms to recognize and react to potentially or currently damaging stimuli for the body. Unmyelinated nociceptive fibers (also called $\mathrm{C}$ fibers) transduce and conduct noxious stimuli from the periphery to the central nervous system. An intensely unpleasant or painful sensation and a behavioral response are then triggered by the central nervous system to preserve the body's integrity [1].

Cutaneous nociceptors are sensitive to mechanical, thermal, and chemical stimuli [2]. In the dermis, unmyelinated nociceptors' axons are ensheathed by a specialized type of glial cells called Remak Schwann cells in a Remak bundle of axons [3].

So far, nociceptive fibers were thought to lose their Remak Schwann cell ensheathment in the dermis, reaching the epidermis as "free nerve endings" [4]. Therefore, few studies have analyzed the involvement of non-myelinating Schwann cells in nociception. 
Abdo et al. [5] in their recent report has focused on the morphology of non-myelinating Schwann cells at the dermis-epidermis border, and on their role in cutaneous nociception in the mouse.

\section{Morphological characterization of a new glial cell type in the skin: the nociceptive Schwann cell}

The authors first studied the morphology and localization of non-myelinating Schwann cells (SCs) in mice skin sections. Genetically modified mice producing fluorescent proteins in non-myelinating SCs and nociceptive fibers were used. Immunohistochemistry, electron microscopy, and immunoelectron microscopy studies were performed on mice hind paw and back skin sections. Unmyelinated nociceptors and glial cell markers were used to study the localization of these cells at the dermis/epidermis border.

With these visualization techniques, the authors found SCs ensheathing nociceptive fibers in the dermis. This glio-neural complex resembles that of the Remak bundle of axons [3]. At the epidermal boundary, Abdo et al. has also observed SCs penetrating into the epidermis, abutting the long-thought "free" nerve endings of nociceptive fibers [4], in both hairy and glabrous skin (Fig. 1A). A layer of fibrillar collagen was seen to be structurally oriented in the glioneural complex direction: it may act by supporting and insulating the complex.

Thus, a morphologically distinct type of SCs has been discovered by Abdo et al. As these SCs are in close relationship with nociceptive fiber terminals in the dermis and epidermis, the authors decided to name them nociceptive Schwann cells.

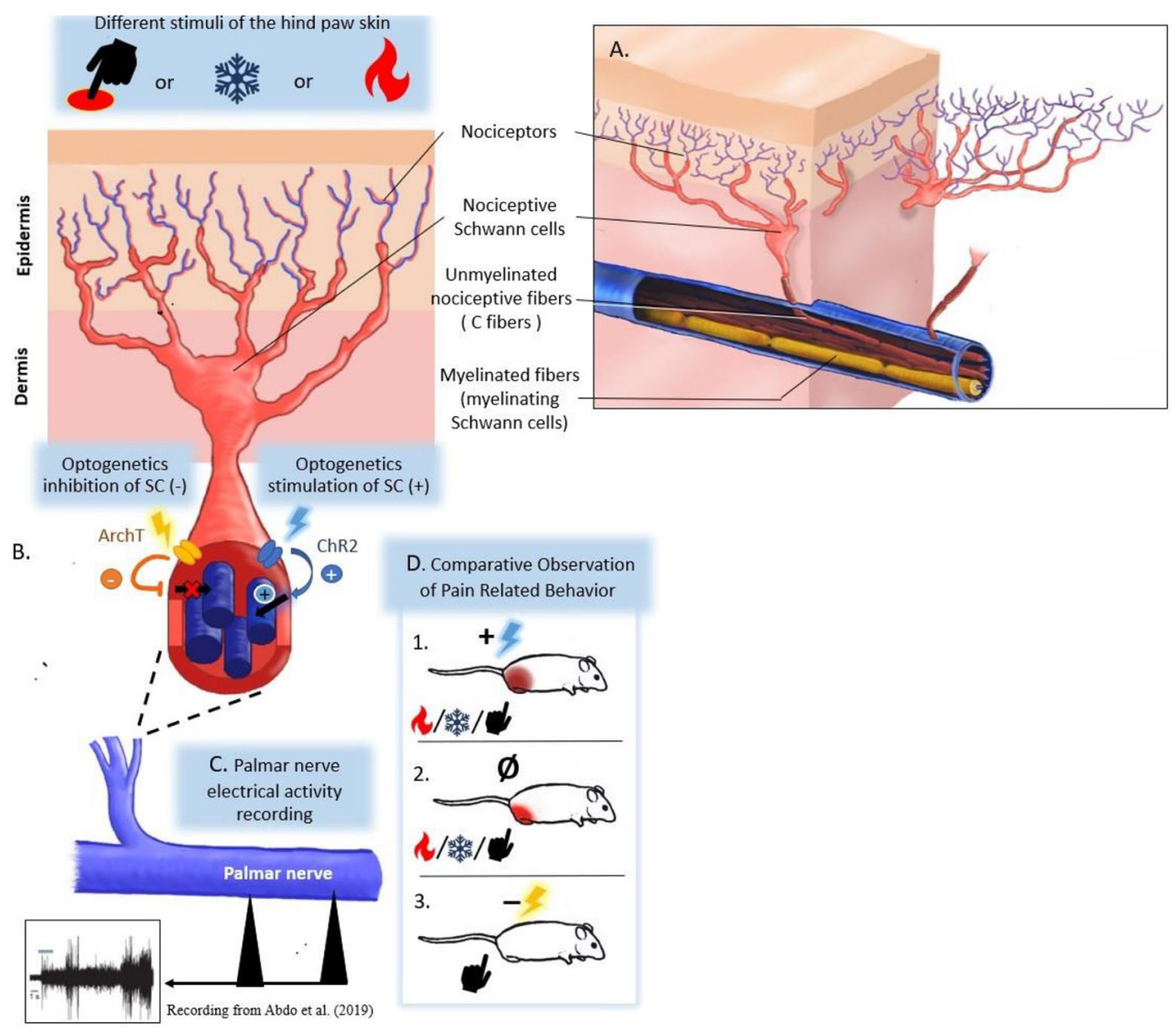

Fig. 1 Specialized Schwann cells form a sensory organ in the skin A. Specific Schwann (nSCs) cells engulf free nerve endings and form a mesh-like network. B. Genetically modified nSCs expressing rhodopsin (ChR2) or archaerhodopsin (ArchT) channels. Specific wavelength modulates the cells activity. C. nSCs optogenetic stimulation elicits nociceptive fibers compound action potential (Palmar nerve recording). $\mathrm{D}_{1}$. nSCs subthreshold optogenetic: stimulation results in potentiation of mechanical and thermal stimuli. $\mathrm{D}_{2}$. Control: mice behavioral response to thermal or mechanical stimulation without optogenetics. $\mathrm{D}_{3}$. nSCs optogenetics: inhibition results in lower response to mechanical stimuli 


\section{Stimulation of nociceptive Schwann cells triggers an electrical response in nociceptive fibers and nocifensive behaviors}

As nociceptive Schwann cells (nSCs) seem to form a structural complex with nociceptors, Abdo et al. then studied the role they could play in nociception. They decided to use an optogenetic strategy to stimulate them in mice palmar skin of the hind paw. Using a virus to infect the cells of this region, they made $n S C$ s produce a specific light-sensitive ion channel called Channelrhodopsin 2 (ChR2) at their membrane surface. By this way, they were able to specifically activate nSCs using blue light (Fig. 1B).

During optogenetic activation of nSCs, they measured the extracellular electrical response of the palmar nerve. They showed a dose-dependent increase in nociceptive fibers firing activity following nSCs stimulation with blue-light trains (Fig. 1C). They also observed an increase in pain-like behaviors after specific stimulations of nSC: paw withdrawal, licking, shaking, and guarding (Fig. $1 \mathrm{D}_{1}$ ).

Hence, this study provides direct evidence that nSCs induce pain-like behaviors by stimulating the nerve endings, which then convey the information to the central nervous system to trigger behavioral responses.

\section{Nociceptive Schwann cells contribute to skin mechanosensitivity and potentiate skin thermosensitivity}

Abdo et al. went further and studied the specific sensory modalities that nociceptive Schwann cells could modulate. They measured if the stimulation of nSCs could elicit a sensitization of mice to mechanical or thermal noxious stimuli. For doing this process, they stimulated nSCs with blue light, exposing mice to a stimulation not sufficient enough to induce pain-like behaviors and simultaneously conducted a stimuli on skin. They also created mice-expressing Archaerhodopsin receptors, called ArchT receptors, at the nSCs membrane. These light-sensitive proteins, instead of activating Schwann cells, inhibit them when exposed to yellow light. They looked at the effect of nSCs inhibition in mice pain sensitivity.

Mice sensitivity to mechanical stimuli was increased by $\mathrm{nSCs}$ activation in a dose-dependent manner: a longer stimulation of $\mathrm{nSCs}$ resulted in an increased sensitivity to mechanical stimulation (Fig. $1 \mathrm{D}_{1}$ ) compared to control (Fig. $1 \mathrm{D}_{2}$ ). Conversely, the mechanical sensitivity was significantly decreased when $\mathrm{nSCs}$ were inhibited (Fig. $1 \mathrm{D}_{3}$ ). Researchers carried on the study by figuring out on what extent these nSCs were affected by mechanical stimuli. They measured their electrical response to mechanical stimuli performing electrophysiological recordings of single nociceptive Schwann cells ex vivo. Abdo et al. showed that a mechanical stimulation elicits a fast-electrical response. From these experiments, they concluded that nociceptive Schwann-cells are inherently mechanosensitive and contribute to the sensation of mechanical stimuli in the skin.

Both heat and cold sensitivity was increased by the nSCs blue light stimulation (Fig. 1D $\mathrm{D}_{1}$ ). However, thermal sensitivity was not significantly reduced in mice expressing the ArchT receptors compared to the control mice. This means that, contrary to mechanical sensitivity, activation of nSCs only potentiates thermal sensitivity. Indeed, the contribution of nociceptive Schwann cells is not required for this modality: nociceptors could be sufficient for the detection of thermal stimuli in mice skin.

\section{Conclusion}

Abdo et al. characterized a new type of glial cells present into mice skin's dermis and epidermis. In the dermis, these non-myelinating Schwann cells resemble the previously described Remak Schwann cells, as they ensheath nociceptive fibers [3]. Contrary to Remak Schwann cells, they were shown to penetrate the epidermis abutting the long-thought "free" nerve endings of nociceptors [4]. Hence, they named them nociceptive Schwann cells (nSCs). Their stimulation generates an electrical response characteristic of the activity of nociceptive fibers and nocifensive behaviors. A lighter stimulation of nSCs increases mice sensitivity to mechanical stimuli while their inhibition lowers mice mechanosensitivity. Abdo et al. also showed that nSCs are inherently mechanosensitive and hypothesized that they could detect noxious mechanical stimuli and stimulate nociceptive fibers in return, directly contributing to mechanical nociception. Activation of nSCs also sensitized mice to noxious thermal stimuli, but their activity is not required for this modality. Nociceptors could be sufficient for thermal nociception, and nSCs activation could only potentiate thermal nociception in mice skin. More research is needed to clarify the role of nSCs in thermoception.

This article challenges the perspective we had of skin nociception. Nociceptive Schwann cells have a singular morphological and functional relationship with nerve fiber terminals. These glial cells are able to activate nociceptors and trigger pain-like behavior. They are inherently mechanosensitive and potentiate thermoception. The contribution of nSCs suggests a broader response profile of nociceptors: the sensory modality that they encode is not only dependent on their molecular profile [6,7] but also on their glio-neural complex. Further research is needed to characterize nociceptive Schwann cells more precisely and maybe to evaluate their involvement and therapeutic potential in some neuropathologies such as chronic pain. 
Acknowledgments This journal club report has been written in the course of the Joint Master in Neuroscience training program (teaching unit: fundamental in neuroscience) with the support of the French National Research Agency (ANR) through the Programme d'Investissement d'Avenir (contract ANR-17-EURE-0022, EURIDOL graduate school of pain)

Conflicts of interests: The authors declare that they have no conflict of interest

\section{References}

1. Woolf CJ, Ma Q (2007) Nociceptors-noxious stimulus detectors. Neuron 55:353-64
2. Svensson CI, Sorkin LS (2017) Neuronal regulation of pain and inflammation. In: Firestein GS, Budd RC, Gabriel SE, et al (eds) Kelley and Firestein's textbook of rheumatology, 10th edn, pp 461-74. Kelley and Firestein's

3. Griffin JW, Thompson WJ (2008) Biology and pathology of non myelinating Schwann cells. Glia 56:1518-31

4. Cauna N (1973) The free penicillate nerve endings of the human hairy skin. J Anat 115:277-88

5. Abdo H, Calvo-Enrique L, Lopez JM, et al (2019) Specialized cutaneous Schwann cells initiate pain sensation. Science 365: 695-99

6. Li C, Wang S, Chen Y, et al (2017) Somatosensory neuron typing with high-coverage single-cell RNA sequencing and functional analysis. Neurosci Bull 34:200-7

7. Zeisel A, Hochgerner H, Lönnerberg P, et al (2018) Molecular architecture of the mouse nervous system. Cell 174:9991014.e22 